Geeraerts, Dirk. 2002. "The scope of diachronic onomasiology". In Vilmos Agel, Andreas Gardt, Ulrike Hass-Zumkehr \& Thorsten Roelcke (red.), Das Wort. Seine strukturelle und kulturelle Dimension. Festschrift für Oskar Reichmann zum 65. Geburtstag 29-44. Tübingen: Niemeyer.

\title{
The scope of diachronic onomasiology
}

\section{Dirk Geeraerts}

University of Leuven

What could be a more fitting tribute to Oskar Reichmann than a contribution to diachronic onomasiology ? The purpose of the present paper - brief though it is - is threefold: first, to chart the domain of onomasiology, determining its various subfields and their mutual relationships; second, to define the specific position of diachronic onomasiology in the context of this classification, and third, to situate my own recent contributions to onomasiological research against the backdrop of this overview of the state of the art. The first aspect expands and revises the suggestions about the internal constitution of the field of onomasiology that I made elsewhere (Geeraerts 1999a). Although I suspect that the classification that I will present here is still amenable to substantial improvement, I do feel that it is more balanced and comprehensive than my earlier attempt.

I would also like to point out that the references to the literature that I will be giving are obviously not intended to be exhaustive. I hope, though, that they are representative of what is going on in contemporary onomasiology. Also, I will restrict my remarks to onomasiological research of a theoretical nature. Descriptive onomasiology as it exists in the form of the onomasiological dictionary will be left unmentioned - though not because I consider the topic to be less worthy of attention (see Geeraerts 2000).

\section{Distinctions within the field of onomasiology}

A conceptual map of the field of onomasiology should be based on at least the following five distinctions:

- the distinction between structural and pragmatic onomasiology,

- the distinction between the qualitative and the quantitative aspects of lexical structures,

- the distinction between referential and non-referential types of meaning,

- the distinction between lexicogenetic mechanisms and sociolexicological mechanisms,

- the distinction between synchronic and diachronic onomasiology.

Keeping in mind that our ultimate purpose is to reach a clearer picture of what diachronic onomasiology could be, we will now have a closer look at the first four distinctions. In the final paragraph of the paper, we will see how these various aspects of onomasiology link up with diachronic onomasiology.

1. Although it has hardly found its way to the canonical English terminology of linguistics (it is absent, for instance, from the indexes of reference works such as Collinge 1990 or Bright 1992), the distinction between onomasiology and semasiology is a traditional one in Continental structural semantics and the Eastern European tradition of lexicological research. The following quote from Baldinger illustrates the distinction quite nicely.

"Semasiology ... considers the isolated word and the way its meanings are manifested, while onomasiology looks at the designations of a particular concept, that is, at a multiplicity of expressions which form a whole" (1980: 278). 
The distinction between semasiology and onomasiology, then, equals the distinction between meaning and naming: semasiology takes its starting-point in the word as a form, and charts the meanings that the word can occur with; onomasiology takes its starting-point in a concept, and investigates by which different expressions the concept can be designated, or named.

However, the two descriptions of onomasiology that Baldinger mentions are not exactly equivalent. On the one hand, studying "a multiplicity of expressions which form a whole" leads directly to the traditional, structuralist conception of onomasiology, i.e. to the study of semantically related expressions (as in lexical field theory, or the study of the lexicon as a relational network of words interconnected by links of a hyponymical, antonymical, synonymous nature etc.). On the other hand, studying "the designations of a particular concept" opens the way for a contextualized, pragmatic conception of onomasiology, involving the actual choices made for a particular name as a designation of a particular concept or a particular referent.

This distinction can be further equated with the distinction between an investigation of structure, and an investigation of use, or between an investigation of langue and an investigation of parole. The structural conception deals with sets of related expressions, and basically asks the question: what are the relations among the alternative expressions ? The pragmatic conception deals with the actual choices made from among a set of related expressions, and basically asks the question: what factors determine the choice for one or the other alternative ?

2. In order to tackle the latter question in a systematic fashion, yet another distinction has to be envisaged, viz. that between what may roughly be described as the qualitative versus the quantitative aspects of linguistic semantic structure.

The distinction may be introduced by considering semasiological structures first. Qualitative aspects of semasiological structure involve the following questions: which meanings does a word have, and how are they semantically related ? The outcome is an investigation into polysemy, and the relationships of metonymy, metaphor etc. that hold between the various readings of an item. Quantitative aspects of lexical structure, on the other hand, involve the question whether all the readings of an item carry the same structural weight. The semasiological outcome of a quantitative approach is an investigation into prototypicality effects of various kinds, as will be obvious to anyone who has followed the developments in semasiological research of the last two decades: prototypicality research is basically concerned with differences of structural weight among the members or the subsenses of a lexical item. The qualitative perspective is a much more traditional one in semasiological lexicology than the quantitative one, which was taken up systematically only recently, with the birth and development of prototype theory.

The distinction between qualitative and quantitative aspects of semantic structure can be extrapolated to onomasiology. The qualitative question then takes the following form: what kinds of (semantic) relations hold between the lexical items in a lexicon (or a subset of the lexicon) ? The outcome, clearly, is an investigation into various kind of lexical structuring: field relationships, taxonomies, lexical relations like antonymy and so on. The quantitative question takes the following onomasiological form: are some categories cognitively more salient than others, that is, are there any differences in the probability that one category rather than another will be chosen for designating things out in the world ? Are certain lexical categories more obvious names than others ? Again, this type of quantitative research is fairly new. The bestknown example to date is Berlin \& Kay's basic level model (Berlin \& Kay 1969, Berlin 1978), which involves the claim that a particular taxonomical level constitutes a preferred, default level of categorization. The basic level in a taxonomy is the level that is (in a given culture) most 
naturally chosen as the level where categorization takes place; it has, in a sense, more structural weight than the other levels.

The relationship between this type of "quantitative" onomasiology and the pragmatic perspective mentioned in the previous point probably does not need further clarification. A particular onomasiological structure (like a level in taxonomy) can be identified as a preferred level of categorization only by taking into account the pragmatic perspective, i.e. the actual choices language users make from among a set of alternative possibilities.

It will also have become obvious at this point that the terms qualitative and quantitative as used here are not in all respects adequate. Fundamentally, what is at issue here is the distinction between the mere presence of an item within a structure and the structural weight of that item, or, if one wishes, between the presence of an item and the preference language users may have for that item. The terms quantitative and qualitative are only used to avoid cumbersome paraphrases expressing this distinction.

3. The distinction between referential (denotational) and non-referential (connotational) aspects of meaning will be clear enough in itself. It involves the distinction between the descriptive aspects of lexical expressions (the contribution they can make to the propositional content of sentences) and their emotive, stylistic or discursive value. As is well-known, there is a general bias in lexical semantics towards the study of referential rather than non-referential meanings. The terminology for describing emotive values, for instance, is much less developed and much less stable than that for describing semasiological links of a referential nature, like metaphor and metonymy: the common terminology has never moved beyond a few traditional concepts like euphemism, taboo, meliorative and pejorative change.

From an onomasiological point of view, this relative lack of attention is to be specifically regretted, because the ties between non-referential meaning and onomasiology are perhaps even stronger than those between non-referential meaning and semasiology. There are two reasons for this.

In the first place, the very definition of non-referential meaning involves the concept of onomasiological alternatives. When, in fact, do we invoke the notion of non-referential meaning ? We may say that a word has a specific non-referential meaning either when its communicative value differs from that of a referential synonym, or when its communicative value cannot be defined in referential terms. The latter case involves the meaning of expressions like hello! What the expression does (i.e. to perform the speech act of greeting) cannot be defined in purely descriptive terms; the expression does not describe a state of affairs or a process, but it performs an action. In the same way, the word yuck does not describe aversion, but expresses it. In cases such as these, we say that hello has a discursive meaning, or that $y u c k$ has an emotive meaning. When comparing dead and deceased or departed, on the other hand, the terms do have an identifiable referential value. At the same time, their communicative value is not identical: deceased and departed are less straightforward and slightly more euphemistic than dead - that is to say, they differ in non-referential value although their referential values are equivalent. In cases such as these, the non-referential value correlates with the presence of referentially equivalent alternatives, i.e. with an onomasiological state of affairs.

In the second place, it is only through the incorporation of non-referential meaning that we can hope to get a clearer view of the way in which lexical innovations spread through a linguistic community. It is important, in this respect, to distinguish between lexical changes that do and do not involve conceptual innovations. On the one hand, a conceptual change as meant here is not identical with a semasiological change (a word acquiring a new meaning), but is meant to refer to the introduction of new concepts as such into the language, regardless of the way in which they are lexically expressed (through the use of loan words, or through the productive coining of 
a neologism, or through the semasiological expansion of an existing word, or through whatever onomasiological process). Lexical changes as meant here, on the other hand, broadly involve all changes in the lexical inventory of the language, i.e. all changes in the language's inventory of pairs of words and meanings. When, for instance, the older English form gate loses its meaning "pathway" in favour of words like road, path, and way, no new concept is introduced, but the distribution of the concepts over the available lexical forms changes.

Lexical innovations, then, may and may not be accompanied by a conceptual innovation. For instance, the introduction of the loan word Computer into German initially involves the spread of the concept "computer"; it seems safe to assume that the basic motif behind this simultaneous introduction of a conceptual and a lexical innovation is a common expressive need on the part of the language users. The driving force behind the spread of the concept "computer" and the word Computer is basically just the growing familiarity of language users with this new piece of equipment. Conversely, when the word Rechner is introduced as an alternative term for Computer, the concept "computer" is already there. (At least, I assume it is for the sake of the argument. Computer and Rechner may have been introduced simultaneously, but I am not familiar enough with the micro-history of German to check whether this was indeed the case.)

Now, if we are to understand anything of the factors behind the competition between Computer and Rechner, we necessarily have to take into account their non-referential values: the differences they exhibit with regard to their stylistic value, and which may determine the preference for one or the other term. These values will necessarily have to include the sociolinguistic distribution of the terms: if, in accordance with the well-known mechanisms of sociolinguistics, either of them wins out because it belongs to a prestigious variety of the language, then this sociolinguistic characterization of the item belongs to its non-referential meaning. Moreover, sociolinguistics as used here is to be taken in the broadest possible sense: whether a word is typical for a learned register, for a rural dialect, for an expert jargon, for a trendy youth culture or for an upper class sociolect are all aspects of its sociolinguistic character, and this sociolinguistic character is part and parcel of its non-referential meaning.

This implies, in other words, that the non-referential value of lexical items involves not just their emotive, stylistic or discursive value, as mentioned above, but their variational value at large, including all possible kinds of sociolinguistic characteristics.

4. On the basis of what was just said, it is now a relatively straightforward matter to explain the difference between lexicogenesis and sociolexicology. Lexicogenesis involves the mechanisms for introducing new pairs of word forms and word meanings - all the traditional mechanisms, in other words, like word formation, word creation (the creation of entirely new roots), borrowing, blending, truncation, ellipsis, folk etymology and others, that introduce new items into the onomasiological inventory of a language. Crucially, the semasiological extension of the range of meanings of an existing word is itself one of the major mechanisms of onomasiological change - one of the mechanisms, that is, through which a concept to be expressed gets linked to a lexical expression. In this sense, the study of onomasiological changes is more comprehensive than the study of semasiological changes, since it encompasses the latter (while the reverse is obviously not the case).

It is a traditional temptation to talk about lexicogenetic mechanisms as if they play a role within the language as such. We might then say, for instance, that German borrows Computer from English. But the language as such is obviously not an anthropomorphic agent: what happens is that individual language users act in a specific way (say, by using a loan word), and that these individual acts lead to changes at the level of the language as a whole - that is, at the level of the speech community. Keller (1990) has introduced a revealing terminology to describe this kind of phenomenon. Borrowing a term from economical theory, he suggests that linguistic change may be described as an "invisible hand" process. As applied to economics, the invisible hand 
metaphor involves two levels of analysis. On the micro-level, the economic life of a community consists of countless individual actions and transactions. Macro-economically, however, these individual actions result in global phenomena, such as inflation or an economic boom. Crucially, the individuals who engage in the basic transactions do not have the conscious private intention of, for instance, changing the rate of inflation. Nor do they act in accordance with a collective decision. Rather, phenomena like inflation are a cumulative consequence on the macro-level of a myriad of individual acts on the micro-level. Similarly, changes spread through a linguistic community as if guided by an invisible force, whereas the actual process involves a multitude of communicative acts.

The invisible hand metaphor, however, stops short of indicating precisely how the transition from the individual level to the global level occurs. What exactly are the mechanisms that enable the cumulative effects ? Logically speaking, two situations may occur: either the changes work in parallel, or they take place serially. The first situation occurs when members of a speech community are confronted with the same communicative, expressive problem, and independently choose the same solution. The introduction of computer as a loan from English into German (and many other languages) may at least to some extent have proceeded in this way. More or less simultaneously, a number of people face the problem of giving a name to the new thing in their native language; independently of each other, they then adopt the original name that comes with the newly introduced object.

The second type occurs when the members of a speech community imitate each other. For instance, when one person introduces a loan word, a few others may imitate him, and they in turn may be imitated by others, and so on. In the same way, the overall picture of a traffic jam is one in which a great number of cars appear to be halted by an invisible hand, while what actually happens is a cumulative process of individual actions: when the first car brakes to avoid a dog running over the highway, the car behind it has to slow down to avoid an accident, and so on.

Studying how onomasiological changes spread through a speech community is typically an aspect of sociolexicology as meant here: beyond merely identifying onomasiological mechanisms in the traditional etymological vein, we need to study how these mechanisms are put at work and how they may lead to overall changes in the habits of the language community. In short, classifications of lexicogenetic mechanisms merely identify the space of possible or virtual onomasiological changes; sociolexicology studies the actual realization of the changes. Needless to say, the latter approach coincides with the pragmatic perspective (it concentrates on the actual onomasiological choices made by language users), and it crucially involves all the non-referential values mentioned above (as factors that may influence these choices).

In the final paragraph of this paper, we will explore to what extent these various aspects of onomasiology might be brought together into a single encompassing schema, and where diachronic onomasiology fits in exactly. As an intermediate step, however, we will check what various traditions of lexical semantics have contributed to the development of onomasiology.

\section{The contribution of various traditions of research}

The various traditions of lexical semantics have contributed in different ways to the study of onomasiology. The traditions that I find useful to distinguish in the present context (cf. Geeraerts 1999a) are the following:

- prestructuralist semantics, as dominant between 1870 and 1930, and as represented by the work of Paul, Bréal, Darmesteter, Wundt, and many others;

- structuralist semantics, as dominant between 1930 and 1960, and as represented by the work of Trier, Weisgerber, Coseriu, Lyons and lexical field theorists at large; 
- generativist and neogenerativist semantics, as originated in the 1960s, and as originally represented by the early work of Katz, Bierwisch, Leech and other theoreticians of componential semantics, and currently by the Generative Lexicon approach of Pustejovsky and his followers;

- cognitive semantics, as originated in the 1980 s, and as represented by the work of Lakoff, Langacker, Talmy and others.

Of these four traditions, all except the generativist/neogenerativist have made noteworthy contributions to the field of onomasiology.

1. Prestructuralist semantics - apart from coining the term onomasiology itself (Zauner 1902) has introduced some of the basic terminology for describing lexicogenetic mechanisms. Although basically concerned with semasiological changes, the major semasiological treatises from Bréal (1897) and Paul (1880) to Stern (1931) and Carnoy (1927) do not restrict themselves to strictly semasiological mechanisms like metaphor and metonymy, but also devote attention to mechanisms of onomasiological change like borrowing or folk etymology. In fact, an insufficiently clear demarcation between onomasiological and semasiological mechanisms may well be a major point of criticism with regard to these earlier studies. Characteristically, there is a certain degree of overlap among the overviews given by Kronasser (1952) and Quadri (1952) of semasiological and onomasiological research respectively.

While the distinction between the two perspectives is treated more systematically in the structuralist era, attempts to classify lexicogenetic mechanisms continue to the present day. Different proposals may be found in the work of, among others, Dornseiff (1966), Algeo (1978, 1980), Tournier (1985, 1987), Zgusta (1990). It lies beyond the scope of the present article to systematically compare these proposals, but it may be noted that there is no single, universally accepted classification.

2. Structuralist semantics makes two important contributions to onomasiology. First, it insists, in the wake of De Saussure himself, on the distinction between semasiology and onomasiology. In the realm of diachronic linguistics, this shows up in Ullmann's classification of semantic changes $(1951,1962)$, or in Baldinger's argumentation (1964) for studying the interplay between semasiological and onomasiological changes. More importantly, the bulk of (synchronic) structuralist semantics is devoted to the identification and description of different onomasiological structures in the lexicon, such as lexical fields, taxonomical hierarchies, lexical relations like antonymy and synonymy, and syntagmatic relationships. These phenomena are fairly well-known; readers in need of an introduction might consult Lutzeier (1995) as a good starting-point. From the point of view of the classification presented above, structuralist semantics is mainly situated within the field of "qualitative" synchronic onomasiology: it concentrates on onomasiological structures within the (synchronic) lexicon.

Second, structuralist semantics has identified one of the possible explanatory factors for onomasiological change, viz. homonymic clashes (Gilliéron \& Roques 1912). Gilliéron claims that homonymy is a pathological situation that calls for curative devices, viz. the therapeutic elimination of one of the homonyms. Analogously, some structuralists also consider polysemy to be a pathological situation that engenders therapeutic measures (see e.g. Goossens 1969); at the same time, the extent to which avoidance of homonymy actually engenders changes has been critically debated (Williams 1944). Avoidance of homonymy and avoidance of polysemy both derive from the idea that there exists an isomorphism between the form and the content of natural languages, a principle that is summarized in the maxim 'one form, one meaning'. Although this isomorphic principle is presented as a structural cause for change, the most realistic way of interpreting it is to accept that it ultimately relies on communicative mechanisms: in some communicative situations, homonymy may lead to difficulties of understanding, and such homonyms may eventually be avoided by the language users. In this respect, 
avoidance of homonymy may be considered a first example of a pragmatic perspective in onomasiology (although it has to be admitted, at the same time, that actual research into homonymy at the level of parole is scarce).

3. There are at least three important contributions that cognitive semantics has made to onomasiology (for basic introductions to cognitive semantics, see Taylor 1995, Ungerer \& Schmid 1996, Violi 1997). This level of interest of the cognitive approach for onomasiology is not surprising, by the way. If Cognitive Linguistics is very much involved with categorization as a basic cognitive function, then the onomasiological perspective is indeed a natural one: from the point of view of the speaker, the basic act of categorization is the onomasiological choice of a category to express a certain idea. So, what are the contributions of cognitive semantics to onomasiological research?

First, cognitive semantics has drawn the attention to a number of "qualitative" onomasiological structures that did not come to the fore in the structuralist tradition. This holds true, on the one hand, for the development of the Fillmorean frame model of semantic analysis (Fillmore 1977, 1985, Fillmore \& Atkins 1992). Frames constitute a specific type of syntagmatic structure in the lexicon that received little or no attention in the structuralist tradition. An instructive attempt to situate frames against the tradition of structuralist semantics can be found in Post (1988). On the other hand, the seminal introduction of generalized metaphor research in the line of Lakoff \& Johnson (1980; see Lakoff \& Turner 1989, Lakoff \& Johnson 1999 for further developments) can be seen as the identification of figurative lexical fields: the ensembles of near-synonymous metaphors studied as "conceptual metaphors" constitute fields of related metaphorical expressions (just like ordinary semantic fields consist of ensembles of near-synonymous lexical items).

Second, cognitive semantics introduces a "quantitative" perspective into the study of onomasiological structures. As mentioned above, basic level research in the line of Berlin and Kay introduces the notion of salience (which is well-known in cognitive semantics through the semasiological research into prototypicality) into the description of taxonomical structures: basic levels are preferred, default levels of categorization.

Third, cognitive semantics introduces a "quantitative" perspective into the study of lexicogenetic mechanisms. Within the set of lexicogenetic mechanisms, some could be more salient (i.e. might be used more often) than others. Superficially, this could involve, for instance, an overall preference for borrowing rather than morphological productivity as mechanisms for introducing new words, but from a cognitive semantic perspective, there are other, more subtle questions to ask: do the way in which novel words and expressions are being coined, reveal specific (and possibly preferred) ways of conceptualizing the onomasiological targets ? An example of this type of research (though not specifically situated within a cognitive semantic framework) is Alinei's work (e.g. 1996) into the etymological patterns underlying the European dialects: he argues, for instance, that taboo words in the European dialects may be motivated either by Christian or Islamic motifs, or by pre-Christian, pre-Islamic heathen motifs; the "quantitative" perspective then involves the question whether one of these motifs is dominant or not. Within cognitive semantics properly speaking, this type of approach is represented by the search for dominant (or even universal) conceptual metaphors for a given domain of experience. A case in point is the work of Kövecses (1990, with critical remarks in Geeraerts \& Grondelaers 1995). On a broader scale, the etymological research project started by Koch and Blank (Blank \& Koch 1999, Koch 1997), intends to systematically explore motivational preferences in the etymological inventory of the Romance languages. In comparison with much of the metaphor-based research, the approach put forward by Blank and Koch takes into account all possible pathways of lexicalization (and not just metaphor). Moreover, it tries to achieve a broader typological coverage than is often the case. 
Against the background of these types of cognitive semantic research, I would now like to briefly situate my own contributions to diachronic onomasiology (which constitute, in a sense, a sequel to my work in diachronic semasiology as laid down in Geeraerts 1997). Basically, what my research group tries to do is to fill in one of the major blanks in the field of onomasiology, viz. pragmatic onomasiology, as defined above as a parole-based enterprise. Using a corpusbased methodology (see Speelman 1997), we try to identify the various factors that influence the onomasiological choice of a category for talking about a given referent, and their mutual interaction. So far, we have studied the following factors as influential on the selection of a name for a referent:

- the semasiological salience of the referent, i.e. the degree of prototypicality of the referent with regard to the semasiological structure of the category (see Geeraerts, Grondelaers \& Bakema 1994);

- the onomasiological entrenchment of the category represented by the expression ("entrenchment" is a generalization of the notion of onomasiological salience as represented by the notion of basic level: see Geeraerts 1993, Geeraerts, Grondelaers \& Bakema 1994);

- non-referential meanings of an emotive and stylistic kind (see Grondelaers \& Geeraerts 1998);

- contextual features of a classical sociolinguistic and geographical nature, involving the competition between different language varieties (see Geeraerts, Grondelaers \& Speelman 1999).

These studies concentrate on synchronic variation and short term lexical changes. Similar studies, staring from cognitive semantic models or taking a sociolexicological perspective, have been devoted to long term onomasiological changes: Dekeyser (1990, 1991, 1995), Geeraerts (1999b), Molina (2000).

\section{A conceptual map of onomasiology}

Would it now be possible to chart the relationship between the various aspects of onomasiology, as described in the first paragraph, into a single comprehensive schema? Two steps need to be taken.

The foregoing paragraph has revealed that the quantitative approach is not restricted to basic level research (the example with which it was introduced above). Preferential patterns may also be sought within the set of lexicogenetic mechanisms. This means, in other words, that a first approximation of a conceptual map of onomasiology may take the following form.

\begin{tabular}{|l|c|c|}
\hline & $\begin{array}{c}\text { "qualitative" approaches: } \\
\text { what are the relevant } \\
\text { phenomena ? }\end{array}$ & $\begin{array}{c}\text { "quantitative" approaches: } \\
\text { which phenomena carry more } \\
\text { weight ? }\end{array}$ \\
\hline $\begin{array}{c}\text { (actual) } \\
\text { synchronic structures }\end{array}$ & $\begin{array}{c}\text { research into lexical structures } \\
\text { (fields, taxonomies, frames, } \\
\text { lexical relations etc.) }\end{array}$ & $\begin{array}{c}\text { research into onomasiological } \\
\text { salience (basic levels, } \\
\text { entrenchment) }\end{array}$ \\
\hline $\begin{array}{c}\text { research into lexicogenetic } \\
\text { (virtual) } \\
\text { mechanisms of change } \\
\text { formation, semasiological } \\
\text { extension etc.) }\end{array}$ & $\begin{array}{c}\text { research into preferential } \\
\text { lexicogenetic mechanisms } \\
\text { (dominant metaphors etc.) }\end{array}$ \\
\hline
\end{tabular}


Figure 1

A conceptual map of onomasiological research

Filling in the chart with the names of the research traditions that have made a dominant contribution to each of the various subfields, schematizes the progressive development of onomasiology. The historical development from prestructuralist semantics over structuralist semantics to cognitive semantics implies a gradual enlargement of the field of onomasiological research, from an interest in lexicogenetic mechanisms over research into lexical structures (fields and others) to various "quantitative" approaches taking into account the difference in salience of the onomasiological phenomena.

\begin{tabular}{|l|c|c|}
\hline & $\begin{array}{c}\text { "qualitative" approaches: } \\
\text { what are the relevant } \\
\text { phenomena ? }\end{array}$ & $\begin{array}{c}\text { "quantitative" approaches: } \\
\text { which phenomena carry more } \\
\text { weight } ?\end{array}$ \\
\hline $\begin{array}{c}\text { research into } \\
\text { lexical structures: } \\
\text { (actual) } \\
\text { synchronic structures }\end{array}$ & $\begin{array}{c}\text { research into } \\
\text { structuralist semantics (plus } \\
\text { cognitive semantics) }\end{array}$ & $\begin{array}{c}\text { cognitive semantics } \\
\text { research into }\end{array}$ \\
\hline $\begin{array}{c}\text { lexicogenetic mechanisms: } \\
\text { prestructuralist semantics }\end{array}$ & $\begin{array}{c}\text { research into preferential } \\
\text { lexicogenetic mechanisms: } \\
\text { mechanisms of change }\end{array}$ \\
\hline
\end{tabular}

Figure 2

Research traditions within onomasiology

The second step is to recognize the central position of pragmatic onomasiology and sociolexicology for a full picture of onomasiology. There are two aspects to this central position, one connected with the input of onomasiological acts, and one connected with their output.

To begin with, pragmatic onomasiology combines the actual structures and the virtual mechanisms: the input for any onomasiological act (the act of naming, the act of choosing a category) is always both the set of already available expressions, and the set of expressions that is virtually available through the presence of lexicogenetic mechanisms. Choosing an expression can in fact take the form of selecting an option that is already there, or of creating a new alternative on the basis of one of the mechanisms. (There are, incidentally, additional reasons for treating the existing structures and the lexicogenetic mechanisms together: they are less clearly separated than may be suggested by the overview. Specifically, whether a lexical item is - psychologically speaking - readily available for use in the individual's mental lexicon is probably a matter of degree rather than a dichotomy.)

Further, onomasiological change cannot be understood unless we take into account pragmatic onomasiology: changes are always mediated through the onomasiological choices made on the level of parole. Words die out because speakers refuse to choose them, and words are added to the lexical inventory of a language because some speakers introduce them and others imitate these speakers; similarly, words change their value within the language because people start using them in different circumstances. Change, in other words, is the ouput of processes that are 
properly studied in the context of pragmatic onomasiology. To repeat a point made earlier, this pragmatic, parole-based perspective automatically takes the form of a sociolexicological investigation: in choosing among existing alternatives, the individual language user takes into account their sociolinguistic, non-referential value, and conversely, the expansion of a change over a language community is the cumulative effect of individual choices. In this sense, it is only through an investigation into factors determining these individual choices, that we can get a grasp on the mechanisms behind the invisible hand of lexical change.

The overall picture, then, looks as follows.

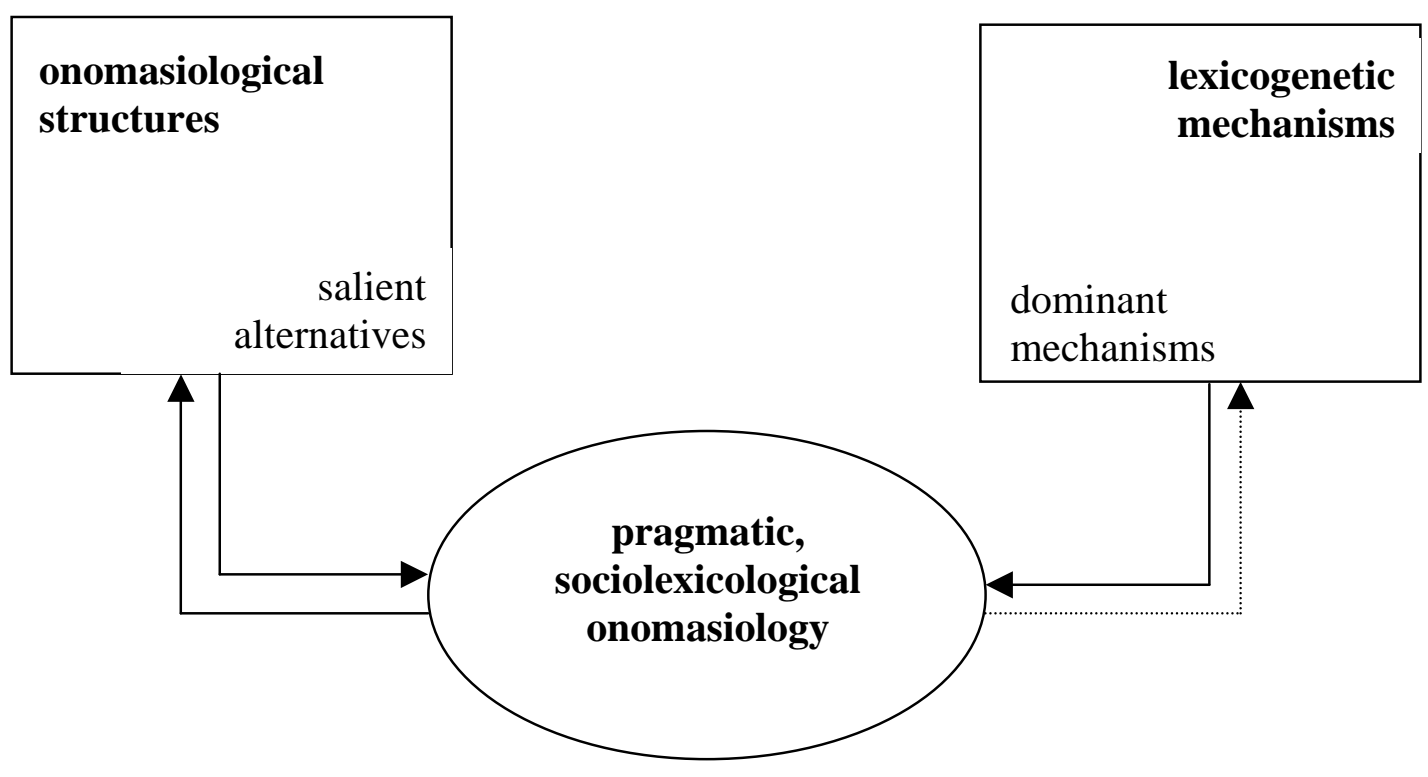

Figure 3

The central position of pragmatic onomasiology

The boxes to the left and to the right repeat the first and the second row of Figure 1. Within each box, the boldface captions identify the "qualitative" aspects, whereas the other captions identify the "quantitative" approaches. The arrows pointing away from the boxes indicate that both boxes constitute input for the processes that play at the pragmatic level: an act of naming may draw from the potential provided by the lexicogenetic mechanisms, or it may consist of choosing among alternatives that are already there. The arrows pointing towards the boxes indicate how the pragmatic choices may lead to change. These processes will primarily affect the actual synchronic structures, through the addition or removal of senses or items, shifts in the variational value of expressions, or changes in the salience of certain options. Secondarily (hence the dotted arrow) a change may affect the lexicogenetic mechanisms, for instance when a particular lexicalization pattern becomes more popular.

Onomasiological research at the level of parole, in other words, is central to the whole onomasiological enterprise; it mediates between what is virtual and what is actual, it combines the traditional "qualitative" approaches and the recent "quantitative" 
innovations, it naturally includes an interest in the non-referential, variational values of lexical items, and it makes the invisible hand visible.

\section{References}

Algeo, J. 1978. "The taxonomy of word making". Word 29: 122-131.

Algeo, J. 1980. "Where do all the new words come from ?". American Speech 55: 264-277.

Alinei, M. 1996. "Aspetti teoretici della motivazione". Quaderni di Semantica 17: 7-17.

Baldinger, K. 1964. "Sémasiologie et onomasiologie". Revue de linguistique romane 28: 249272.

Baldinger, K. 1980. Semantic Theory. Oxford: Basil Blackwell. Translation of Teoría semántica. Hacia una semántica moderna. Madrid: Ediciones Alcalá 1977.

Berlin, B. 1978. "Ethnobiological classification". In Eleanor Rosch \& Barbara B. Lloyd (eds.), Cognition and Categorization 9-26. Hillsdale, NJ: Lawrence Erlbaum.

Berlin, B. \& P. Kay 1969. Basic Color Terms. Their Universality and Evolution. Berkeley: University of California Press.

Blank, A. \& P. Koch 1999. "Onomasiologie et étymologie cognitive: l'exemple de la tête". In Mario Vilela \& Fatima Silva (eds.), Actas do $1^{\circ}$ Encontro Internacional de Linguística Cognitiva 49-72. Porto: Faculdade de Letras.

Bréal, M. 1897. Essai de sémantique. Paris: Hachette.

Bright, W. 1992. International Encyclopedia of Linguistics. New York and Oxford: Oxford University Press.

Carnoy, A. 1927. La science du mot. Traité de sémantique. Leuven: Editions Universitas.

Collinge, N.E. 1990. An Encyclopedia of Language. London and New York: Routledge.

Dekeyser, X. 1990. "The prepositions with, mid and again(st) in Old and Middle English. A case study of historical lexical semantics". In Dirk Geeraerts (ed.), Diachronic Semantics (Belgian Journal of Linguistics 5) 35-48. Brussel: Editions de l'Université de Bruxelles.

Dekeyser, X. 1991. "Romance loans in Late Middle English: a case study". In Sylviane Granger (ed.), Perspectives on the English Lexicon. A Tribute to Jacques van Roey (Cahiers de l'Institut de Linguistique de Louvain 17.1/3) 153-162. Louvain-la-Neuve: Cabay.

Dekeyser, X. 1995. "Travel, journey and voyage. An exploration into the realm of Middle English lexico-semantics". North-Western European Language Evolution 25: 127-136.

Dornseiff, F. 1966. Bezeichnungswandel unseres Wortschatzes. Ein Blick in das Seelenleben der Sprechenden. Lahr/Schwarzwald: Moritz Schauenburg Verlag.

Fillmore, C. 1977. "Scenes-and-frames semantics". In Antonio Zampolli (ed.), Linguistic structures processing 55-81. Amsterdam: North Holland Publishing Company. 
Fillmore, C. 1985. "Frames and the semantics of understanding". Quaderni di Semantica, 6: 222-255.

Fillmore, C. \& B. Atkins 1992. "Towards a frame-based lexicon: the semantics of risk and its neighbors". In Adrienne Lehrer \& Eva Feder Kittay (eds.), Frames, Fields, and Contrasts. New Essays in Semantic and Lexical Organization 75-102. Hillsdale, NJ: Lawrence Erlbaum.

Geeraerts, Dirk. 1993. "Generalised onomasiological salience". In Jan Nuyts \& Eric Pederson (eds.), Perspectives on Language and Conceptualization (Belgian Jounal of Linguistics 8) 43-56. Brussel: Editions de l'Université de Bruxelles.

\section{Geeraerts, Dirk. 1997. Diachronic Prototype Semantics. A Contribution to Historical} Lexicology. Oxford: Clarendon Press.

Geeraerts, D. 1999a. "Hundred years of lexical semantics". In Mario Vilela \& Fatima Silva (eds.), Actas do $1^{o}$ Encontro Internacional de Linguística Cognitiva 123-154. Porto: Faculdade de Letras.

Geeraerts, D. 1999b. "Vleeshouwers, beenhouwers en slagers. Het WNT als bron voor onomasiologisch onderzoek". Nederlandse Taalkunde 4: 34-46.

Geeraerts, D. 2000. "Adding electronic value. The electronic version of the Grote Van Dale". In Ulrich Heid, Stefan Evert, Egbert Lehmann \& Christian Rohrer (eds.), The Ninth Euralex International Congress Proceedings I: 75-84. Stuttgart: Institut für Maschinelle Sprachverarbeitung.

Geeraerts, D. \& S. Grondelaers 1995. "Looking back at anger. Cultural traditions and metaphorical patterns". In John Taylor \& Robert E. MacLaury (eds.), Language and the Construal of the World 153-180. Berlin: Mouton de Gruyter.

Geeraerts, D., S. Grondelaers \& P. Bakema 1994. The Structure of Lexical Variation. Meaning, Naming, and Context. Berlin: Mouton de Gruyter.

Geeraerts, D., S. Grondelaers \& D. Speelman 1999. Convergentie en divergentie in de Nederlandse woordenschat. Een onderzoek naar kleding- en voetbaltermen. Amsterdam: Meertens Instituut.

Gilliéron, J. \& M. Roques 1912. Etudes de géographie linguistique. Paris: Champion.

Goossens, J. 1969. Strukturelle Sprachgeographie. Heidelberg: Carl Winter Universitätsverlag.

Grondelaers, S. \& D. Geeraerts 1998. "Vagueness as a euphemistic strategy". In Angeliki Athanasiadou \& Elzbieta Tabakowska (eds.), Speaking of Emotions: Conceptualisation and Expression 357-374. Berlin: Mouton de Gruyter.

Keller, R. 1990. Sprachwandel. Von der unsichtbaren Hand in der Sprache. Tübingen: Francke Verlag.

Koch, P. 1997. "La diacronica quale campo empirico della semantica cognitiva". In Marco Carapezza, Daniele Gambarara \& Franco Lo Piparo (eds.), Linguaggio e cognizione. Atti del XXVIII Congresso Internazionale della Società di Linguistica Italiana 225-246. Roma: Bulzoni. 
Kövecses, Z. 1990. Emotion concepts. New York: Springer.

Kronasser, H. 1952. Handbuch der Semasiologie. Kurze Einführung in die Geschichte, Problematik und Terminologie der Bedeutungslehre. Heidelberg: Carl Winter Universitätsverlag.

Lakoff, G. \& M. Johnson 1980. Metaphors We Live By. Chicago: The University of Chicago Press.

Lakoff, G. \& M. Johnson 1999. Philosophy in the Flesh. The Embodied Mind and its Challenge to Western Thought. New York: Basic Books.

Lakoff, G. \& M. Turner 1989. More than Cool Reason. A Field Guide to Poetic Metaphor. Chicago: The University of Chicago Press.

Lutzeier, P. 1995. Lexikologie. Ein Arbeitsbuch. Tübingen: Stauffenburg Verlag.

Molina, C. 2000. "Give sorrow words". Reflexiones semanticas y lexicologicas en torno al dolor en la lengua inglesa desde la diacronia cognitiva. $\mathrm{PhD}$ Thesis, Universidad Complutense de Madrid.

Paul, H. 1880. Prinzipien der Sprachgeschichte. Halle: Max Niemeyer Verlag.

Post, M. 1988. "Scenes-and-frames semantics as a neo-lexical field theory". In Werner Hüllen \& Rainer Schülze (eds.), Understanding the Lexicon. Meaning, Sense, and World Knowledge in Lexical Semantics 36-47. Tübingen: Max Niemeyer Verlag.

Quadri, B. 1952. Aufgaben und Methoden der onomasiologischen Forschung. Eine entwicklungsgeschichtliche Darstellung. Bern: Francke Verlag.

Speelman, D. 1997. Abundantia Verborum. A computer tool for carrying out corpus-based linguistic case studies. PhD Thesis, University of Leuven.

Stern, G. 1931. Meaning and Change of Meaning. Göteborg: Elanders.

Taylor, J. 1995. Linguistic Categorization. Prototypes in Linguistic Theory, 2nd ed. Oxford: Clarendon Press.

Tournier, J. 1985. Introduction à la lexicogénétique de l'anglais contemporain. Paris: Champion, Genève: Slatkine.

Tournier, J. 1987. Précis de lexicologie anglaise. Paris: Nathan.

Ullmann, S. 1951. The Principles of Semantics. Oxford: Basil Blackwell, Glasgow: Jackson, Son and Co..

Ullmann, S. 1962. Semantics. An Introduction to the Science of Meaning. Oxford: Basil Blackwell.

Ungerer, F \& H.-J. Schmid 1996. An Introduction to Cognitive Linguistics. London and New York: Longman.

Violi, P. 1997. Significato ed esperienza. Milano: Bompiani. 
Williams, E.R. 1944. The Conflict of Homonyms in English. New Haven: Yale University Press.

Zauner, A. 1902. Die romanischen Namen der Körperteile. Eine onomasiologische Studie. $\mathrm{PhD}$ Thesis, Universität Erlangen. Published in Romanische Forschungen (1903) 14: 339-530.

Zgusta, L. 1990. "Onomasiological change". In Edgar C. Polomé (ed.), Research Guide on Language Change 389-398. Berlin: Mouton de Gruyter. 